\title{
Effects of varying dietary protein levels on the performance of laying japanese quail(Coturnix coturnix japonica) in a semi-arid environment
}

\section{S. Babangida and C.O. Ubosi}

Department of Animal Science, University of Maiduguri, P.M.B 1069, Maiduguri, Borno StateNigeria.

\section{Abstract}

Four dietary treatments differing in protein levels were compared to ascertain the protein requirement of laying Japanese quall in a semi-arid environment. One hundred and twenty quails were randomly assigned to four treatments (T1 - 22\%CP, T2 - 20\%CP, T3 - 18\%CP and T4$16 \% \mathrm{CP}$ ) in a completely randomized block design. Each treatment was replicated thrice with ten quails each. Feed intake, body weight gain, hen day egg production, feed conversion ratio (FCR), egg quality and haematological constituents were the response criteria. The study lasted seven weeks. Feed and water were provided ad libitum throughout the experimental period. No significant $(P>0.05)$ effect of dietary protein was observed for feed intake, average body weight gain, hen-day egg production, $F C R$, dressing percentage and haematological parameters. Average body weight was significantly $(P<0.05)$ enhanced by high dietary protein. Egg weight and Haugh unit were significantly $(P<0.05)$ better for the groups fed the higher protein levels $(20$ and $22 \% C P$ ). Hen-day egg production, albumen index, specific gravity, shell weight and percent shell were not affected $(P>0.05)$ by dietary protein levels. The costs of producing $l \mathrm{~kg}$ egg in the treatment groups were

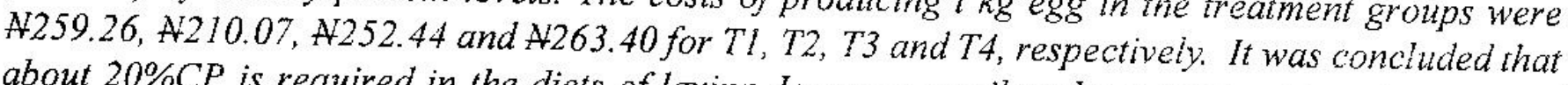
about $20 \% \mathrm{CP}$ is required in the diets of laying Japanese quail under a semi-arid environment of
Nigeria.

Key words: Crude protein, productive parameters, Japanese quail

\section{Introduction}

The Japanese quail (Coturnix coturnix japonica) which is now being bred for meat and egg (Cooper, 1989) has the potential to serve as an excellent and cheap source of animal protein for Nigerians. According to NRC (1991), quails are so precocious that they can lay eggs when hardly more than five weeks old, and it is said that about twenty of them are sufficient to keep an average family in eggs all year round.

Currently, there is a dearth of information on the nutritional requirement of the quail in Nigeria. Most of the diets used for feeding the birds are based on requirements for temperate regions of the world. In the semi-arid region where ambient temperature is usually high and relative humidity is low (Alaku, 1982), it would be expected that protein intake and its utilization by the Japanese quail would be affected (NRC, 1984).

It is a known fact that dietary protein affects the productive performance of poultry (NRC, 1984). It has been reported by several workers that dietary protein affects body weight, feed conversion efficiency, egg production and haemtology of Japanese quail (Zelenka, et al., 1984; Annaka et al., 1993; Murakami et al., 1993a,b; Shrivastar et al., 1994; Ahmad et al., 1994). 
$-\ldots$ objective of this study was to determine the $\because z$ its of varying dietary protein levels on the - Cormance, egg quality, haematology and cost groduction of Japanese quail as means of Ezertaining their protein requirement in a semi$\therefore$ environment.

\section{Materials and Methods}

\section{Experimental Site}

- he experiment was conducted at the University Maiduguri. Maiduguri falls within the semizrid region of North Eastern Nigeria. This study was conducted in the University's Teaching and Research Farm. Maiduguri has an altitude of $354 \mathrm{~m}$ above sea level and it is characterized by a typical sub-sahelian weather with a short duration of rainfall usually 3 to 4 months mostly between July and October. The period from March to June is extremely hot particularly during the day averaging 40 to $45^{\circ} \mathrm{C}$ while the night temperature range between 33 and $35^{\circ} \mathrm{C}$. The relative humidity during the period averages $35 \%$. The ambient temperature during the harmattan (December to February) could be as low as 5 to $10^{\circ} \mathrm{C}$.

\section{Flock Management and Experimental Design}

One hundred and twenty Japanese quails (Coturnix coturnix japonica) were obtained from the National Veterinary Research Institute (NVRI), Vom, Plateau State. The birds were brooded on deep litter and then transferred to colony cages measuring $76 \times 50 \times 30 \mathrm{~cm}(\mathrm{~L} \times \mathrm{B}$ $\mathrm{x} \mathrm{H}$ ) at four weeks of age, prior to the start of the experiment. At six weeks of age, the birds were assigned to four dietary treatments (T1 $22 \% \mathrm{CP}$, $\mathrm{T} 2-20 \% \mathrm{CP}, \mathrm{T} 3-18 \% \mathrm{CP}$ and $\mathrm{T} 4-16 \% \mathrm{CP}$ ) of thirty birds each in a completely randomized block design. The treatments were replicated thrice. The experimental diets were formulated with local ingredients (Table 1). Feed and water were provided ad libitum throughout the seven weeks of the experimental period.
Feed consumption, body weight, feed conversion ratio, hen-day egg production, haematological parameters, dressing percentage and feed cost constituted the response criteria. Mean body weights were recorded first at the beginning of the experiment and weekly thereafter. Feed consumption was recorded daily. Blood was collected from five birds in each treatment at the last week of the experiment from the jugular vein, using a 23 gauge needle. These birds were subsequently slaughtered and used to obtain the dressing percentages of the carcass.

During the $7^{\text {th }}$ week of study, eggs were collected for determination of egg weight and egg specific gravity, albumen index, Haugh unit, shell weight and shell thickness. Eggs were collected twice daily for two consecutive days in each occasion. Eggs laid in the night were removed from the cages the following morning to ensure that only those eggs that were laid within the same time were evaluated. The eggs that were gathered in the late afternoon were refrigerated at $10^{\circ} \mathrm{C}$ overnight and broken out the following morning. Twelve eggs were randomly selected from each treatment group for determination of the above parameters. Individual albumen height and diameter measurements were taken immediately after eggs had been removed from the refrigerator. The shell thickness was obtained from shell with the membrane still intact and measured to the nearest $0.01 \mathrm{~mm}$ using Goldcross micrometer screw guage. Albumen height and diameter were measured to the nearest $0.01 \mathrm{~mm}$. Albumen index was calculated while Archimedes principle was used for determination of the specific gravity of the eggs (Hamilton, 1982). Haugh unit was calculated from the formular given by Haugh (1937). The proximate compositions of the experimental diets were determined according to the methods outlined by AOAC (1980). Energy values were calculated using the formula of Ichhponani (1980). Data from the study were subjected to Analysis of Variance 
(Anova) using a completely randomized block design and means which differed $(\mathrm{P}<0.05)$ significantly were separated using the least square difference (Steel and Torrie, 1980).

\section{Results and Discussion}

The mean weekly minimum and maximum temperature of the poultry house recorded during

Table 1. Gross composition of experimental Diets $(\%)$

\begin{tabular}{|c|c|c|c|c|}
\hline Ingredients & $\mathrm{Tl}(22 \% \mathrm{CP})$ & $\mathrm{T} 2(20 \% \mathrm{CP})$ & $\mathrm{T} 3(18 \% \mathrm{CP})$ & $\mathrm{T} 4(16 \% \mathrm{CP})$ \\
\hline Maize & 46.54 & 50.92 & 54.75 & 58.24 \\
\hline Wheat bran & 15.51 & 16.97 & 18.25 & 19.41 \\
\hline Groundnut cake & 15.33 & 12.72 & 10.02 & 7.39 \\
\hline Full fat soyabean & 12.26 & 10.17 & 8.02 & 5.91 \\
\hline Blood meal & 3.07 & 2.54 & 2.01 & 1.48 \\
\hline Beniseed & 0.80 & 0.18 & 0.45 & 1.07 \\
\hline Bone meal & 6.00 & 6.00 & 6.00 & 6.00 \\
\hline Salt & 0.25 & 0.25 & 0.25 & 0.25 \\
\hline *Premix & 0.25 & 0.25 & 0.25 & 0.25 \\
\hline \multicolumn{5}{|c|}{$\begin{array}{l}\text { Proximate composition } \\
\text { Crude protein }\end{array}$} \\
\hline Crude protein & 22.15 & 20.19 & 17.98 & 16.37 \\
\hline Crude fibre & 4.47 & 4.50 & 4.54 & 4.60 \\
\hline Ether Extract & 7.25 & 8.00 & 6.80 & 6.10 \\
\hline Ash & 10.26 & 11.97 & 9.79 & 10.81 \\
\hline Dry matter & 95.50 & 95.20 & 96.50 & 97.08 \\
\hline$* *$ NFE & 49.84 & 48.54 & 54.43 & 55.80 \\
\hline${ }^{*} \mathrm{ME}$ Kcal $\left./ \mathrm{kg}\right)$ & 2897 & 2853 & 2880 & 2829 \\
\hline
\end{tabular}

Each $2.5 \mathrm{~kg}$ optimix vit/min. premix contain; vit. A $10,000,000$ i.u, vit $\mathrm{D}_{3} 2,000000 \mathrm{iu}$, vit $\mathrm{E} 10,000 \mathrm{iu}$, vit. K $2000 \mathrm{mg}$, Thiamine $\left(B_{1}\right) 1500 \mathrm{mg}$, Riboflavin $\left(B_{2}\right) 400 \mathrm{mg}$, Pyridoxine $\left(B_{6}\right) 1500 \mathrm{mg}$, Niacin 15,000 $\mathrm{mg}$, vit. $\mathrm{B}_{12} 10 \mathrm{mg}$, Pantothenic acid 5,000 mg, Folic acid $500 \mathrm{mg}$, Biotin $20 \mathrm{mg}$, Choline chloride $200 \mathrm{mg}$, Antioxidant $125 \mathrm{mg}$, Manganese $80 \mathrm{~g}$, Zinc $50 \mathrm{~g}$, Iron $20 \mathrm{~g}$, Copper $5 \mathrm{~g}$, Iodine $1.2 \mathrm{~g}$, Selenium $200 \mathrm{mg}$, Cobalt $200 \mathrm{mg}$. (Manufactured by Animal Care, Nigeria Ltd.).

* ME - Metabolizable Energy. ${ }^{* *} \mathrm{NFE}$ - Nitrogen free Extract.

Table 2 shows the results of some of the parameters measured in the experiment. Treatment effects were not significant $(\mathrm{P} \geq 0.05)$ for feed intake. This observation was in agreement with reports of Crivelli et al. (1982) and Murakami et al. (1993a) who observed no significant effect of dietary proteins on feed intake of Japanese quail. The overall mean protein consumption per bird in treatments $\mathrm{T} 1$, $\mathrm{T} 2, \mathrm{~T} 3$, and $\mathrm{T} 4$ were $4.12 \mathrm{~g}, 3.78 \mathrm{~g}, 3.43 \mathrm{~g}$ and
$2.94 \mathrm{~g}$ protein per day, respectively. Allen and Young (1980) reported that quails fed a cornsoyabean basal diet appeared to require an intake of about $3.5 \mathrm{~g}$ protein/day. Although the overall average daily feed intake recorded in this experiment was below those earlier reported for mature quail (Yamane et al., 1979; Arscott and Pierson-Geoger, 1981), it was assumed that the higher ambient temperatures of the semi-arid region accounted for the smaller feed intake (Yamane et al., 1979). 
Babangida and Ubosi

Table 2. Influence of dietary protein on productive performance of Japanese quail

\begin{tabular}{|c|c|c|c|c|c|}
\hline I-ameter & $\begin{array}{l}\mathrm{T} 1 \\
(22 \% \mathrm{CP})\end{array}$ & $\begin{array}{l}\mathrm{T} 2 \\
(20 \% \mathrm{CP})\end{array}$ & $\begin{array}{l}\mathrm{T} 3 \\
(18 \% \mathrm{CP})\end{array}$ & $\begin{array}{l}\mathrm{T} 4 \\
(16 \% \mathrm{CP})\end{array}$ & SEM \\
\hline$\therefore$ erage daily feed intake (g) & 18.73 & 18.92 & 19.03 & 18.35 & $0.19^{155}$ \\
\hline$\therefore$ arage weekly body weight / bird (g) & $161.00^{\mathrm{a}}$ & $161.11^{\mathrm{a}}$ & $156.82^{\mathrm{b}}$ & $156.33^{b}$ & $1.14^{*}$ \\
\hline $\begin{array}{l}\therefore \text { arage weekly body weight change } \\
\therefore \text { rd (g) }\end{array}$ & 9.42 & 9.37 & 8.56 & 8.82 & $1.33^{\mathrm{NS}}$ \\
\hline$\because$ n day egg production $(\%)$ & 35.28 & 43.33 & 30.28 & 36.39 & $4.42^{\mathrm{NS}}$ \\
\hline Zzssing Percentage (\%) & 66.02 & 61.57 & 64.05 & 60.08 & $1.62^{\mathrm{NS}}$ \\
\hline ECR (Body weight) & 5.30 & 4.73 & 5.24 & 4.86 & $0.65^{\mathrm{NS}}$ \\
\hline$=2 R$ (Egg Production) & 11.68 & 9.13 & 10.52 & 13.00 & $0.61^{\mathrm{NS}}$ \\
\hline
\end{tabular}

- FCR - Feed Conversion Ratio, SEM - Standard Error of Mean

$* \quad$ - Significant $(\mathrm{P}<0.05)$

Ns - Not significant $(\mathrm{P}>0.05)$.

$\therefore$ ails fed the higher protein diets ( 22 and $20 \%$ $?$ ? showed significantly $(\mathrm{P}<0.05)$ higher body $\cdots$ ight than those fed the lower protein levels i 8 and $16 \% \mathrm{CP}$ ). There was, however, no :atistical difference among the treatments for - ady weight change. Yamane et al. (1979) - aported that low protein intake significantly zicreased body weight gain of the laying quail. s.milarly, Allen and Young (1980) reported that 5 and 19\% CP did not support body weight as $=20 \mathrm{CP}$ in the diets of laying Japanese quail. $\therefore$ is important to note that body weight has been $\approx$ ported to be the single most important factor sontrolling egg weight for young pullets Summers and Leeson, 1983).

To influence $(P>0.05)$ of dietary protein was sbserved among the treatments on FCR. This agrees with what Crivelli et al. (1982) and Murakami et al. (1993a) reported; that dietary protein level had no significant influence on feed ifficiency when laying quails were fed diets with iifferent protein levels. The varying protein evels had no effect $(\mathrm{P}>0.05)$ on hen-day egg production. This observation is consistent with the report of Allen and Young (1980), which stated that egg production was similar in lapanese quail fed a basal diet of corn-soyabean meal varying in protein level $(16-22 \% \mathrm{CP})$.

Table 3 shows a summary of the effect of varying dietary protein levels on egg quality of Japanese quail in a semi-arid environment. Results of the study showed that dietary protein levels have significant $(\mathrm{P}<0.05)$ effect on egg weight. The $22 \% \mathrm{CP}$ diet supported the production of heavier eggs than the 18 and $16 \% \mathrm{CP}$ diets. This observation is in agreement with the report that egg weight increases with increased dietary protein (Arscott and Pierson-Goeger, 1981; Crivelli et al., 1982; Annaka et al., 1993; Murakami et al., 1993b). Yamane et al. (1979) reported that a good quail egg should weigh about $9.3 \mathrm{~g}$ or more.

Haugh unit was significantly $(\mathrm{P}<0.05)$ affected by dietary protein level. The group fed $22 \% \mathrm{CP}$ had superior Haugh unit value than the other groups $(20,18$ and $16 \% \mathrm{CP})$. However, it is worth noting that none of the varying levels (16$22 \% \mathrm{CP}$ ) of protein recorded Haugh unit lower than the minimum value of 72 Haugh unit required for a grade AA quality egg (North, 1978). This observation agrees with the report of Kling et al. (1985) who showed that Haugh unit was significantly affected by percentage protein in the layer ration of Brown egg type pullets. 
Protein level had no significant $(P>0.05)$ influence on albumen index, shell weight, percent shell and specific gravity. This is in conformity with the reports of other workers (Roland, 1980b, Uddin, 1991, Murakani et al., 1993b)

The overall means for eggshell thickness showed that quail fed $22 \% \mathrm{CP}$ diets produced significantly $(\mathrm{P}<0.05)$ thicker shell than those fed $18 \%$ CP. No specific trend was however observed among the treatment means. This supports the reports of Uddin et al. (1991) and Murakami et al. (1993b), which showed that

Table 3. Influence of varying dietary protein on egg quality

Table 4 shows the results of the influence of dietary protein on the haematological constituents and blood chemistry of the Japanese quail. The result showed no significant $(\mathrm{P}>0.05)$ effect of dietary protein on all the parameters measured. The red blood cell (RBC) count, white blood cell (WBC) count and haemoglobin $(\mathrm{Hb})$ concentration values obtained in this environment were within the ranges for mature quail as earlier reported (Atwal et al., 1964; Woodard et al., 1973; Treatment (CP)

$\begin{array}{llllll}\text { Parameters } & 22 \% & 20 \% & 18 \% & 16 \% & \text { SEM }\end{array}$

\begin{tabular}{lccccc} 
Egg weight $(\mathrm{g})$ & $10.13^{\mathrm{a}}$ & $9.51^{\mathrm{ab}}$ & $8.92^{\mathrm{b}}$ & $8.96^{\mathrm{b}}$ & 0.24 \\
Specific gravity & 1.06 & 1.07 & 1.07 & 1.06 & 0.01 \\
Haugh unit & $85.61^{\mathrm{a}}$ & $83.18^{\mathrm{b}}$ & $83.31^{\mathrm{b}}$ & $83.15^{\mathrm{b}}$ & 0.69 \\
Albumen index & 0.18 & 0.19 & 0.14 & 0.16 & 0.02 \\
Shell weight $(\mathrm{g})$ & 0.79 & 0.76 & 0.71 & 0.73 & 0.02 \\
Percent shell $(\%)$ & 7.80 & 7.99 & 8.00 & 8.16 & 0.16 \\
Shell thickness $(\mathrm{mm})$ & $0.22^{\mathrm{a}}$ & $0.20^{\mathrm{ab}}$ & $0.19^{\mathrm{b}}$ & $0.20^{\mathrm{ab}}$ & 0.01 \\
\hline
\end{tabular}

a,b,c Means in the same row bearing different superscript differ significantly $(\mathrm{P}<0.05)$ SEM - Standard Error of Mean

Spent hens form an important source of poultry meat in Nigeria, hence the need to study the influence of dietary protein on carcass yield of laying Japanese quail. However, no significant effect of protein level was observed on dressing percentages of the experimental birds (Table 2). This observation is similar to what Shrivastar and Panda (1991) reported that although dressing percent showed an increasing trend with increased dietary protein level, it was not statistically different in broiler quails. The average dressing percentages observed in this experiment are consistent with the reported value of about $69.05 \%$ for an unselected line of coturnix (Oguz et al., 1996).
The cost of producing $1 \mathrm{~kg}$ of each diet based on prevailing market prices of feed ingredients at the time of the experiment were $\mathrm{N} 32.53, \mathrm{~N} 31.06$, $\mathrm{N} 29.84$ and $\mathrm{N} 28.85$ for $\mathrm{T} 1, \mathrm{~T} 2, \mathrm{~T} 3$ and $\mathrm{T} 4$, respectively. This observation is consistent with the conclusion that the price of poultry feed is directly related to its level of protein (Ubosi, 1986). The cost of feeding a bird under each experimental diet were $\mathrm{N} 29.85, \mathrm{~N} 28.80, \mathrm{~N} 27.82$ and $\mathrm{N} 25.94$, while $\mathrm{N} 259.26, \mathrm{~N} 210.07, \mathrm{~N} 252.44$, $\$ 263.40$ were the cost of producing $1 \mathrm{~kg}$ of egg for $\mathrm{T} 1, \mathrm{~T} 2, \mathrm{~T} 3$ and $\mathrm{T} 4$ respectively. 
Babangida and Ubosi

4. Influence of dietary protein on haematological constituents and blood biochemistry of Japanese quail

\begin{tabular}{|c|c|c|c|c|c|}
\hline Parameter & $\begin{array}{l}\mathrm{Tl} \\
(22 \% \mathrm{CP})\end{array}$ & $\begin{array}{l}\mathrm{T} 2 \\
(20 \% \mathrm{CP})\end{array}$ & $\begin{array}{l}\text { T3 } \\
(18 \% \mathrm{CP})\end{array}$ & $\begin{array}{l}\mathrm{T} 4 \\
(16 \% \mathrm{CP})\end{array}$ & $\overline{\text { SEM }}$ \\
\hline$\equiv-\times 10^{\circ} \mathrm{mm}^{3}$ & 5.04 & 4.88 & 5.25 & 5.05 & $0.39^{\mathrm{NS}}$ \\
\hline$=5 \times 10^{3} \mathrm{~mm}^{3}$ & 16.60 & 16.46 & 16.80 & 16.90 & $0.95^{\mathrm{NS}}$ \\
\hline$士 \equiv 0)$ & 14.80 & 14.04 & 15.38 & 14.94 & $0.87^{\mathrm{NS}}$ \\
\hline$=(-30)$ & 50.60 & 48.00 & 50.00 & 48.40 & $3.00^{\mathrm{NS}}$ \\
\hline$\therefore=\left(1^{\circ} 0\right)$ & 29.33 & 28.81 & 29.57 & 30.17 & $1.14^{\mathrm{NS}}$ \\
\hline$-\div 大(\%)$ & 29.46 & 29.18 & 30.76 & 31.04 & $0.97^{\mathrm{NS}}$ \\
\hline . i fento litre) & 100.58 & 98.88 & 95.96 & 97.04 & $3.23^{\mathrm{NS}}$ \\
\hline$\tau=$ protein $(\mathrm{g} / \mathrm{dl})$ & 39.00 & 37.20 & 36.40 & 36.00 & $3.77^{\mathrm{NS}}$ \\
\hline Calcium (mmol/L) & 1.74 & 1.66 & 1.80 & 1.52 & $0.17^{\mathrm{NS}}$ \\
\hline 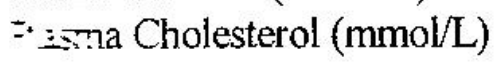 & 3.34 & 3.64 & 3.20 & 3.42 & $0.21^{\mathrm{NS}}$ \\
\hline$=\operatorname{sina}$ Glucose $(\mathrm{mmol} / \mathrm{L})$ & 7.38 & 7.84 & 7.34 & 6.24 & $1.59^{\mathrm{NS}}$ \\
\hline
\end{tabular}

$\Sigma=1$ - Standard error of mean.

.-. - Packed cell volume

- $\mathrm{H}$ - Mean corpuscular haemoglobin

HC - Mean corpuscular haemoglobin concentration

$\therefore$ ' Mean corpuscular volume

$\because \quad$ - Not significant $(P>0.05)$

\section{Conclusion}

-

- int of laying Japanese quail but had no effect

: - :en-day production and haematological

$\therefore$-situents of Japanese quail in the semi-arid

$=-2=$ of Nigeria. In comparison with the other

-

$=\div$ jiet tends to be the most profitable level of

$-r$ inin inclusion for optimum performance. It

2 therefore be concluded that about $20 \% \mathrm{CP}$

$\therefore$ : $=$ quired in the diet of laying Japanese quail

z s semi-arid environment.

\section{References}

thmad, M.K., Barque, A.R., Nawaz, H., Siddiqui, R.H. 1994. Effect of varying. energy and protein levels on the haematology of Japanese quails. Pakistan bet. J. 14(4): 200-202
Alaku, S. O. 1982. The influence of season on birth weight, body weight at 3 and 12 month in Wadara calves in the Sahel region of North-Eastern Nigeria. World Rev. Anim. Prod. 18: 23-32.

Allen, N.K and Young, J. 1980. Studies on the amino acid and protein requirements of laying Japanese Quail (Coturnix coturnix japonica). Poult. Sci. 59: 2029-2037.

Annaka, A., Tomizawa, K. Momose, Y., Watanabe, E. and Ishibashi, T. 1993. Effects of dietary protein levels on performance of Japanese quail. Anim. Sci. and Tech. 64(8):797-806.

Anon. 1980 Guide to the Care and use of experimental animals. Vol.l. Canadian Council on Animal Care, Ottawa, Ontatio, Canada. Pp.85-90. 
AOAC 1980 Official Methods of Analysis, 13ed. Washington DC. Association of Official Analytical Chemists.

Arscott, G.H. and Pierson-Goeger, M. 1981. Protein needs of laying Japanese quail as influenced by protein level and amino-acid supplementation. Nutr. Rep. Int. 24(6) 1287-1295.

Atwal, O.S., McFarland, L.Z. and Wilson, W.O. 1964. Hematology of coturnix from birth to maturity. Poult. Sci.43-1392-1401.

Cooper, A.M. 1989. The Japanese Quail. In The UFAW handbook on the care and management of laboratory animals . $6^{\text {th }} \mathrm{ed}$. Poole, T.B. (ed). Longman group Ltd., London. Pp 678-686.

Crivelli, E.J., Enriquez, V.F. and Arila, G.E. 1982. Study of different levels of protein in diets for breeding female Japanese quail (Coturnix coturnix Japanica). Nutr. Abs. Rev. (Series B) 52(7): 426. No. 3559.

Hamilton, R.M.G. 1982. Methods and Factors that affect the measurement of egg shell quality. Poult. Sci. 61(10) 2022-2039.

Haugh, R.R. 1937. The Haugh unit for measuring egg quality. US Poult. Mag. 43: 552-555.

Ichhponani, J. S. 1980. Developing quick and reliable test to predict biological availability of nutrients in poultry feeds. Final Repot of ICAR Project, PAU, Ludhiana.

Thekoronye, A.I. and Ngoddy, P.O. 1985. Integrated Food Science and Technology. Macmillan Pubishers, London. Pp. 361-362.

Kling, L.J., Hawes, R.O., Gerry, R.W. and Halteman, W.A. 1985. Effects of early maturation of Brown egg-type pullets, flock uniformity, layer protein level and cage design on egg production, egg size and egg quality. Poult. Sci. 64(6): 1050-1059.

Murakami, A.E., Moraes, V.M.B. De, Arikki, J., Junqueira, O.M., Kronka, S. Don. 1993a. Levels of protein and energy in diets of growing Japanese quail (Coturnix coturnix japonica). Revista de Socidade Brasileira de Zootechnia 22(4): 534-540.

Murakami, A.E., Moraes, V.M.B. De, Ariki, J., Junqueeira, O.M., Kronka, S. Don. 1993b. Levels of protein and energy in diets of laying Japanese quail (Coturnix coturnix Japonica). Revista de Sociedade Brasileira de Zootecnia 22(4): 541-551.

North, O.M. 1978. Cage Management. In: Commercial Chick Production Manual. The Avi Publishing Company inc. Westport, Connecticut. Pp 268-306.

NRC 1991. Quail. In: Microlivestock - Little Known Small Animals with a promising economic future. National Academy Press, Washington D.C. Pp 147-155. National Research Council.

NRC 1984. Nutrient Requirements of Poultry. National Academy of Sciences, Washington, D.C. pp. 2-10. National Research Council.

Oguz, I., Attan, O., Kirkpinar, F. and Settar, P. 1996. Body weights, Carcase characteristics, Organ weights, Abdominal fat, and Lipid content of liver and carcase in two lines of Japanese quail (Coturnic coturnix japonica), unselected and selected for four week body weight. Brit. Poult. Sci. 37(3) $579-588$.

Rajini, R.A., and Narahari, D. 1998. Dietary energy and protein requirement of growing 
jecarese quail in the tropics, Indian J. Amin $\Sigma=6810) 1082-1086$.

Wand. D.A., SR. 1980a. Egg Shell Quality I. Efect of dietary manipulation of protein, inino acid, energy and calcium in aged -ans on egg weight, shell weight, shell Fality and egg production. Poult. Sci 59: 2038-2046.

R.tand. D.A., SR. 1980b. Egg Shell Quality II. Effect of dietary manipulation of protein, zmino acid, energy and Calcium in young rens on egg weight, shell weight, shell quality and egg production. Poult Sci.59: 20478-2054

Shrivastar. A.K., and Panda, B. 1991. Effect of age and diet on growth, meat quality and market possibilities of quail broilers. Indian let. Med. J. 15(1): 25-33.

Shrivastar, A.K., Johari, T.S. and Raju, M.V.L.N. 1994. Dietary protein and energy requirements of laying quails recorded under different nutrient schedules during starting and growing period. Indian J. Anim. Sci. 64(2): 173-177.

5emmers, J.D. and Leeson, S. 1983. Factors influencing early egg size. Poult. Sci. 62: 1155-1159.

Steel, R.G.D. and Torrie, J.H. 1980 . Principles and Procedures of Statistics: A Biometrical Approach. $2^{\text {nd }}$ ed. McGraw-Hill, Kpgakusha Ltd., Tokyo.
Ubosi, C.O. 1986. Poultry Production in the livestock industry in Nigeria. Paper presented at the Association of Veterinary Medical Students (AVMS) Symposium. August 28, 1986, at the University of Maiduguri, Nigeria.

Uddin, M.S., Taraque, A.M.M., Howlider, M.A.R. Khan, M.J. 1991. The influence of dietary protein and energy levels on egg quality in starcross layers. Asian-Aust. $J$. Anim. Sci. 4(4): 299-405.

Woodard, A.E., Abplanalp, H., Wilson, W.O. and Vohra, P. 1973. Japanese Quail Husbandary in the Laboratory (Coturnix coturnix japonica). Dept. of Avian Sciences, University of California, Davis, Ca. 95616. 22Pp.

Yamane, T., Ono, K. and Tanaka, T. 1979. Protein requirements of laying Japanese quail. Brit. Poult. Sci. 20: 379-383.

Zelenka, D.J., Cherry, J.A., Nir, I. And Siegel, P.B. 1984. Body Weight and Composition of Japanese quail (Coturnix coturnix japonica) at sexual maturity. Growth 48: 16-28.

(Received 21 August 2004; Accepted 17 May 2005) 